\title{
Boosting Inflammation Resolution in Atherosclerosis
}

\section{The Next Frontier for Therapy}

\author{
Gabrielle Fredman* and Ira Tabas ${ }^{\dagger}$
}

From the Department of Molecular and Cellular Physiology, * Center for Cardiovascular Sciences, Albany Medical College, Albany; and the Departments of Medicine, Pathology and Cell Biology, and Physiology, ${ }^{\dagger}$ Columbia University Medical Center, New York, New York

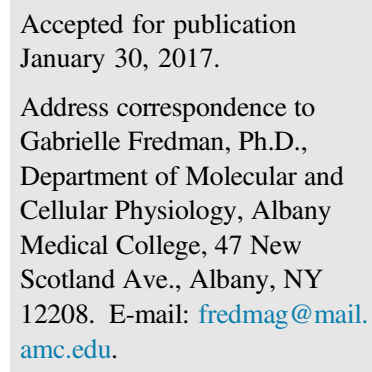

\begin{abstract}
Defective inflammation resolution is the underlying cause of prevalent chronic inflammatory diseases, such as arthritis, asthma, cancer, and neurodegenerative and cardiovascular diseases. Inflammation resolution is governed by several endogenous factors, including fatty acid-derived specialized proresolving mediators and proteins, such as annexin A1. Specifically, specialized proresolving mediators comprise a family of mediators that include arachidonic acid-derived lipoxins, omega-3 fatty acid eicosapentaenoic acid-derived resolvins, docosahexaenoic acid-derived resolvins, protectins, and maresins. Emerging evidence indicates that imbalances between specialized proresolving mediators and proinflammatory mediators are associated with several prevalent human diseases, including atherosclerosis. Mechanisms that drive this imbalance remain largely unknown and will be discussed in this review. Furthermore, the concept of dysregulated inflammation resolution in atherosclerosis has been known for several decades. Recently, there has been an explosion of new work with regard to the therapeutic application of proresolving ligands in experimental atherosclerosis. Therefore, this review will highlight recent advances in our understanding of how inflammation resolution may become defective in atherosclerosis and the potential for proresolving therapeutics in atherosclerosis. Last, we offer insight for future implications of the field. (Am J Pathol 2017, 187: 1211-1221; http:// dx.doi.org/10.1016/j.ajpath.2017.01.018)
\end{abstract}

\section{The Ideal Outcome of the Inflammation Resolution Response Is Tissue Repair and Regeneration}

Acute inflammation, coupled with a timely inflammation resolution response, is a protective process. ${ }^{1}$ When there is a defect in the inflammation resolution program, inflammation persists and collateral tissue damage ensues. ${ }^{1,2}$ However, most inflammatory processes are self-limiting, which implicates the existence of endogenous proresolution pathways. ${ }^{1}$ Although it was previously thought that proinflammatory mediator catabolism was sufficient for inflammation to cease, it is now known that the resolution of acute inflammation is an active, highly coordinated process. ${ }^{1}$ The process is controlled by a variety of endogenous mediators that include the following: i) specialized proresolving mediators (SPMs), such as lipoxins, resolvins, protectins, and maresins ${ }^{1,3,4}$; ii) protein/peptide mediators, such as annexin $\mathrm{A} 1^{5}$ and IL-10; iii) gases, such as carbon monoxide and hydrogen sulfide ${ }^{6,7}$; and iv) nucleotides, such as adenosine and inosine. ${ }^{8}$ As an example, SPMs are actively biosynthesized in local tissue microenvironments at the onset of acute inflammation to counterbalance the numerous proinflammatory signals,

Supported by the NIH grants HL119587 (G.F.), HL132412 (I.T.), HL075662 (I.T.), and HL127464 (I.T.); and the American Federation for Aging Research, Research Grant for Junior Faculty (G.F.).

Disclosures: None declared.

A guest editor acted as the Editor-in-Chief for this manuscript. No person at the Columbia University Medical Center was involved in the peer review or final disposition of this article. 
which controls the magnitude and duration of inflammation. ${ }^{1}$ SPMs each have distinct chemical structures and bind and activate specific G-protein-coupled receptors. ${ }^{1}$ The concentration of SPMs needed to activate these receptors is achieved at their local sites of biosynthesis. ${ }^{1}$ As an example, the concentration of resolvin D1 (RvD1) in local blister exudates from humans is approximately $85 \mathrm{pmol} / \mathrm{L}{ }^{9}$ In a separate study with human macrophages, RvD1 enhanced efferocytosis in the dose ranges of 10 to $100 \mathrm{pmol} / \mathrm{L},{ }^{10}$ thus supporting that low concentrations of SPMs detected in humans are capable of evoking significant biological activity. Furthermore, deletion of key SPM receptors, such as ALX/ FPR2 or GPR18, leads to exacerbated inflammation and defective resolution. ${ }^{11-13}$ These findings provide strong evidence that SPMs are essential endogenous mediators of the inflammation-resolution response. Furthermore, emerging evidence has revealed that the balance of proinflammatory mediators and SPMs during acute inflammation regulates the duration of the inflammatory response and the timing of tissue resolution. ${ }^{14,15}$ SPMs, which are biosynthesized through the actions of lipoxygenases (LOXs), are protective in vivo, and act locally to control leukocyte trafficking and enhance efferocytosis. ${ }^{1}$ As such, SPMs stimulate the host to repair and regenerate tissue and are thus protective in several disease models, including injury-induced neointimal hyperplasia, ${ }^{16,17}$ myocardial infarction, ${ }^{18,19}$ and atherosclerosis, ${ }^{20-24}$ to name a few. This panoply of work suggests that lipid mediator balances and tissue repair/regeneration (rather than a simple blockade of proinflammatory signals) are critical to thwart disease. Moreover, as will be illustrated in the following section, an imbalance between proresolving and proinflammatory mediators has been linked to a number of diverse chronic inflammatory diseases in humans, including atherosclerosis. ${ }^{25-27}$ Furthermore, this review will highlight recent advances in our understanding of how inflammation resolution may become defective in atherosclerosis and the potential for proresolving therapeutics in atherosclerosis.

\section{Imbalances in Proinflammatory and Proresolving Mediators Drive Atheroprogression and Arterial Tissue Injury}

The concept that imbalances in lipid mediators are associated with disease originated shortly after the discovery of thromboxane $\mathrm{A}_{2}$ and prostacyclin. ${ }^{28}$ In this regard, an imbalance in the thromboxane $\mathrm{A}_{2}$ /prostacyclin ratio was thought to provide an explanation for some of the changes occurring in various pathological situations. ${ }^{28,29}$ Another piece of the puzzle was added when Serhan and colleagues ${ }^{30}$ found that angioplasty increased the levels of proresolving lipoxins (eg, lipoxin $\mathrm{A}_{4}$, $\mathrm{LXA}_{4}$ ) and proinflammatory leukotrienes (LTs; eg, $\mathrm{LTC}_{4}$, $\mathrm{LTD}_{4}$ ) in human coronary arterial blood, indicating that coronary arterial cells could perform LT and SPM biosynthesis and thereby affect the balance of mediators. Correlations were reported for high levels of plasma LTs and plaque instability in humans, ${ }^{31}$ and other studies indicated that $\mathrm{LTB}_{4}$ increased recruitment of monocytes and their differentiation to foam cells, ${ }^{32}$ as well as intimal hyperplasia. ${ }^{33}$ Furthermore, cysteinyl LTs have been shown to enhance the recruitment of leukocytes into the arterial wall and to contribute to thrombosis and vascular remodeling. ${ }^{34,35}$ In humans, the incidence of atherosclerosis, stroke, and myocardial infarction in certain populations has been linked to variants of the genes that encode proteins and enzymes required for LT biosynthesis, such as 5-lipoxygenase (5-LOX), 5-LOX-activating protein, and leukotriene $\mathrm{A}_{4}$ (LTA LTydrolase $^{36-39}$ Furthermore, on treatment with a 5-LOX-activating protein inhibitor, $\mathrm{C}$-reactive protein was reduced in one population of patients who had both a history of myocardial infarction and one of the enzyme gene variants mentioned above. ${ }^{40}$ Diet gene interactions have also been extensively studied. ${ }^{41,42}$ For example, individuals with a specific 5-LOX variant who also ingested a diet rich in AA had increased carotid atherosclerosis compared to individuals with nonvariant 5-LOX, whereas those with the same mutation but who ingested a diet rich in omega- 3 fatty acids had less carotid atherosclerosis compared with the control population. ${ }^{41}$ More recent work indicated a trend between eicosapentaenoic acid and a 5-LOX variant in lowering cardiovascular disease (CVD) risk $(P=0.06){ }^{43}$ Further studies need to be performed to determine the functions of these single-nucleotide polymorphisms and to reconcile the results of a few clinical trials that failed to show a protective effect of dietary fish oils. ${ }^{42}$ For example, this variability may be because of a lack of uniformity and quality control of the fish oils being tested, different doses and types of fish oils used, and/or the difficulty of showing beneficial effects on subjects already being treated with other CVD or diabetes drugs. Furthermore, fish oils contain a mixture of substances, only a fraction of which represent $n-3$ polyunsaturated fatty acids. This is the case particularly for marine oils that can also contain fish steroids. In this regard, fish oils should not be considered synonymous with eicosapentaenoic acid and docosahexaenoic acid. Also, there is an absence of data on the uptake and kinetics of eicosapentaenoic acid and docosahexaenoic acid into human tissues.

Although much of the earlier attention was focused on proinflammatory LTs, new results highlight SPMs in CVD (see more details below). For example, support for a role of endogenous biosynthesis of SPMs in limiting atherosclerosis was suggested by a study showing that overexpression of a key SPM biosynthetic enzyme, 12/15-LOX, in chowfed Apoe $^{-1-}$ mice was atheroprotective. ${ }^{20}$ Furthermore, low levels of SPMs in the plasma, including aspirin-triggered $\mathrm{LXA}_{4}$, were reported in patients with vascular disease. ${ }^{44,45}$ As another example, human vulnerable atherosclerotic plaque regions had significantly less 5-LOX-derived SPMs and a significant imbalance between these SPMs and LTs compared with stable plaque regions. ${ }^{22}$ These human plaque findings were also corroborated in murine plaques, where there was a marked imbalance between SPMs and LTs as 
atherosclerosis progressed from early to advanced stage of disease $^{22,23}$ (Figure 1). Possible mechanisms underlying this imbalance include factors that affect the subcellular localization of 5-LOX, such as oxysterols/oxidative stress and SPMs. ${ }^{46}$ We previously uncovered a new pathway that explains, in part, why endogenous SPMs could be defective in inflammatory diseases like atherosclerosis. ${ }^{22,46}$ During inflammation or oxidative stress, 5-LOX is phosphorylated and translocates to the nuclear membrane, which favors the biosynthesis of the proinflammatory mediator, leukotriene $\mathrm{B}_{4}\left(\mathrm{LTB}_{4}\right){ }^{47,48}$ In this context, the SPM RvD1 promoted nuclear exclusion of 5-LOX and thereby suppressed $\mathrm{LTB}_{4}$ and enhanced the proresolving molecule, lipoxin $\mathrm{A}_{4}\left(\mathrm{LXA}_{4}\right)$ in macrophages. ${ }^{46}$ Recent findings have also suggested that 5-LOX-activating protein plays an important role in the production of SPMs. ${ }^{49,50}$ Other processes that can affect SPM production include transcellular biosynthesis between interacting cells ${ }^{1}$ and the release of $\mathrm{LX}$ precursors from cellular phospholipids. ${ }^{51}$ Leukotriene $\mathrm{A}_{4}$ hydrolase is also emerging as an intriguing target for atherosclerosis, because its inhibition has been linked to a decrease in leukotriene $\mathrm{B}_{4}$ and an increase in lipoxins. ${ }^{31,49}$

In sum, SPM imbalances occur in advancing atherosclerotic lesions, which provides a molecular basis for previous observations that advanced atherosclerotic plaques have pathological features of defective resolution. ${ }^{52,53}$

\section{SPM Rescue Impairs Efferocytosis in Advanced Atherosclerotic Plaques}

A common function of SPMs is their ability to enhance noninflammatory clearance of apoptotic cells, or efferocytosis, ${ }^{1,54}$ and thus a defect in SPMs might lead to an

\section{Early/stable plaque}

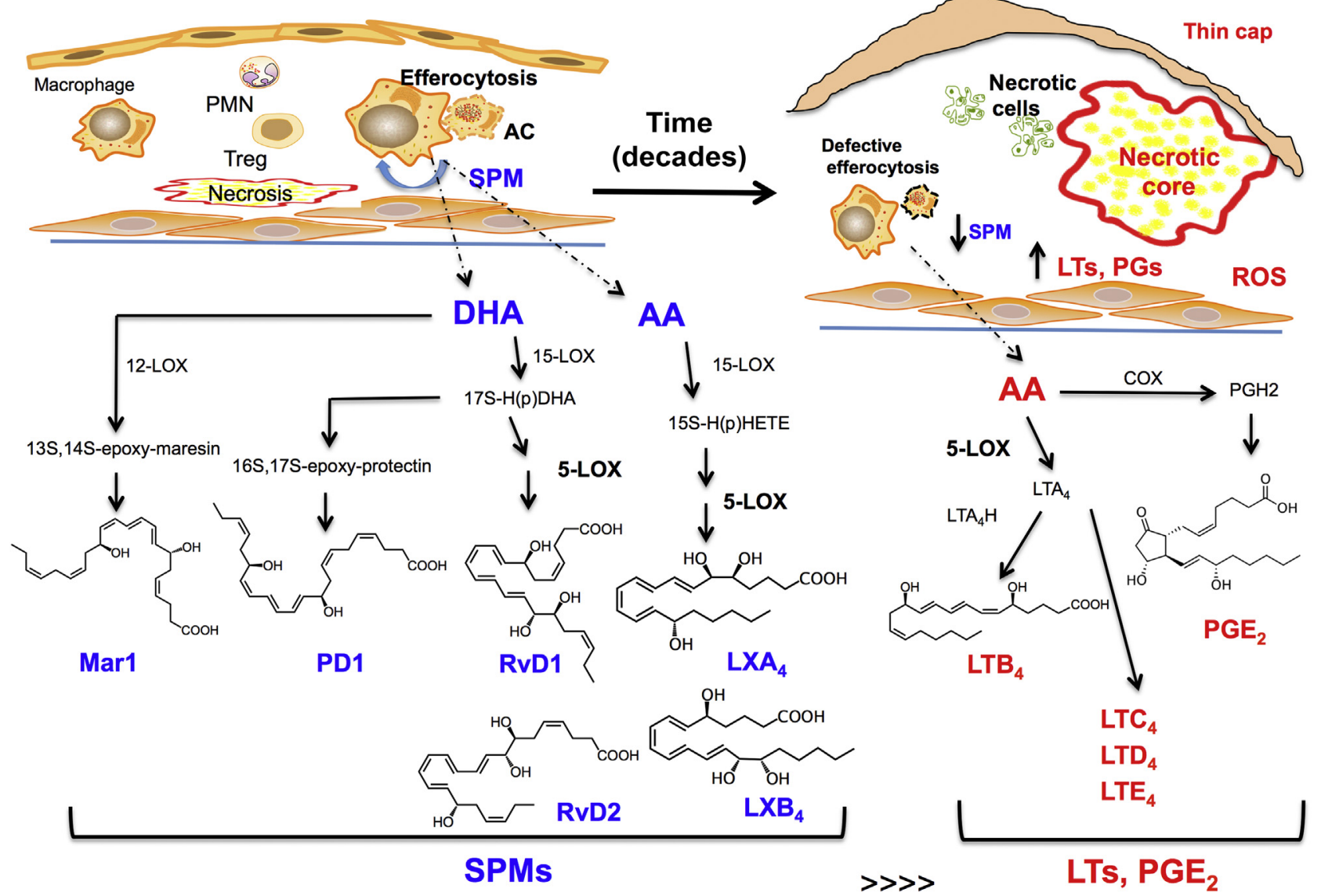

\section{Advanced/vulnerable plaque}

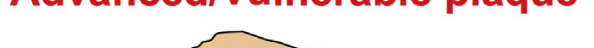


impaired efferocytosis response. Given the importance of defective efferocytosis in necrotic core formation and advanced plaque progression, ${ }^{55}$ a potential therapeutic strategy to boost efferocytosis in atherosclerosis and suppress plaque necrosis would be to restore plaque SPMs. To test this hypothesis, we administered RvD1 to Western diet-fed $\mathrm{Ldlr}^{-1-}$ mice during the time period when earlier lesions progressed to advanced lesions. RvD1 was administered because it was the most significantly decreased SPM as atherosclerosis progressed from the early to advanced stage in $\mathrm{Ldll}^{-1-}$ mice, but several other SPMs were decreased as well. ${ }^{22}$ Nevertheless, we found that RvD1 significantly increased the SPM/LT ratio, enhanced lesional efferocytosis, and decreased plaque necrosis compared with vehicle controls. ${ }^{22}$ These results indicate that addition of key defective SPMs tip the balance toward a more proresolving plaque phenotype (Figure 2). As will be described in more detail below, almost identical results were observed when a peptide mediator of resolution was administered in the same manner as above. ${ }^{56}$ Viola et $\mathrm{al}^{23}$ found that the SPMs maresin 1 and RvD2 decreased as atherosclerosis progressed and that combined administration of maresin 1 and RvD2 to Apoe ${ }^{-1-}$ mice with established atherosclerosis had significantly less necrosis than vehicle controls. Given that maresin 1 and RvD2 enhance efferocytosis in other contexts, ${ }^{1}$ it is likely that enhanced efferocytosis played a role in the observed benefit in this model.

Earlier work demonstrated that MerTK, a key efferocytosis receptor on macrophages, is a critical regulator of plaque necrosis and lesion stability. ${ }^{57,58}$ MerTK can be regulated by a disintegrin and metalloprotease (ADAM)17-mediated cleavage process that disables the receptor and produces a soluble fraction called soluble Mer. In this regard, Thorp et $\mathrm{al}^{59}$ mapped the cleavage site of MerTK, which provided the basis for the generation of a MerTK cleavage-resistant mouse $\left(\right.$ Mertk $\left.^{C R}\right){ }^{60}$ This in vivo tool helped uncover a new function of MerTK, namely, its ability to promote tissue repair and SPM biosynthesis. ${ }^{60}$ In this regard, Mertk ${ }^{C R}$ mice

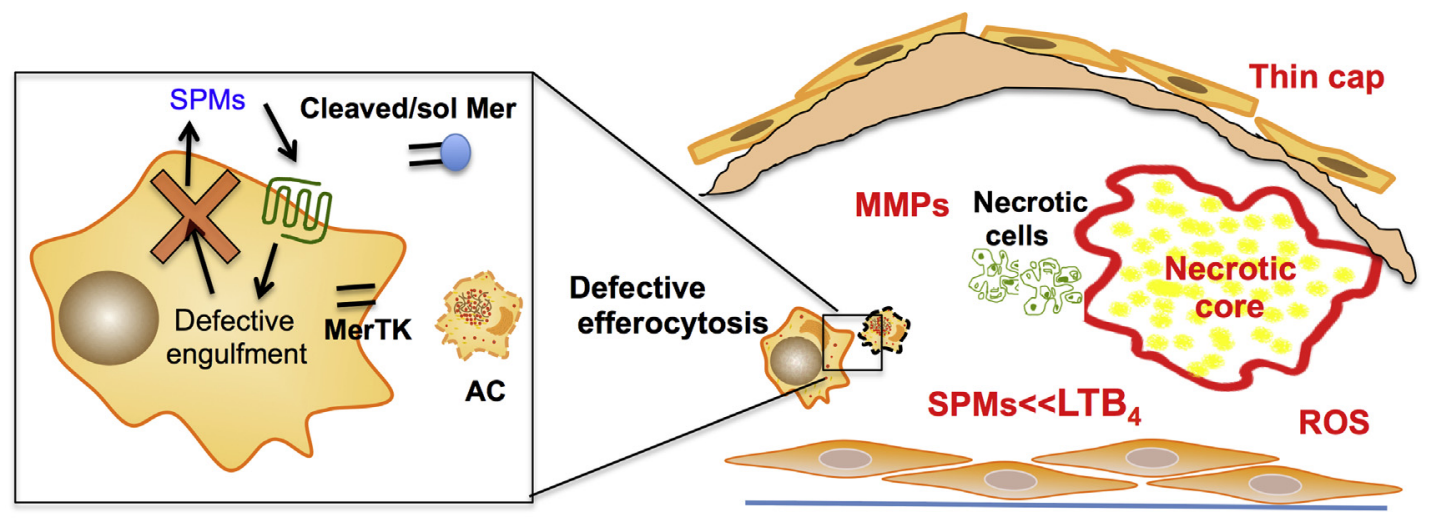

\section{Advanced/ vulnerable plaque}

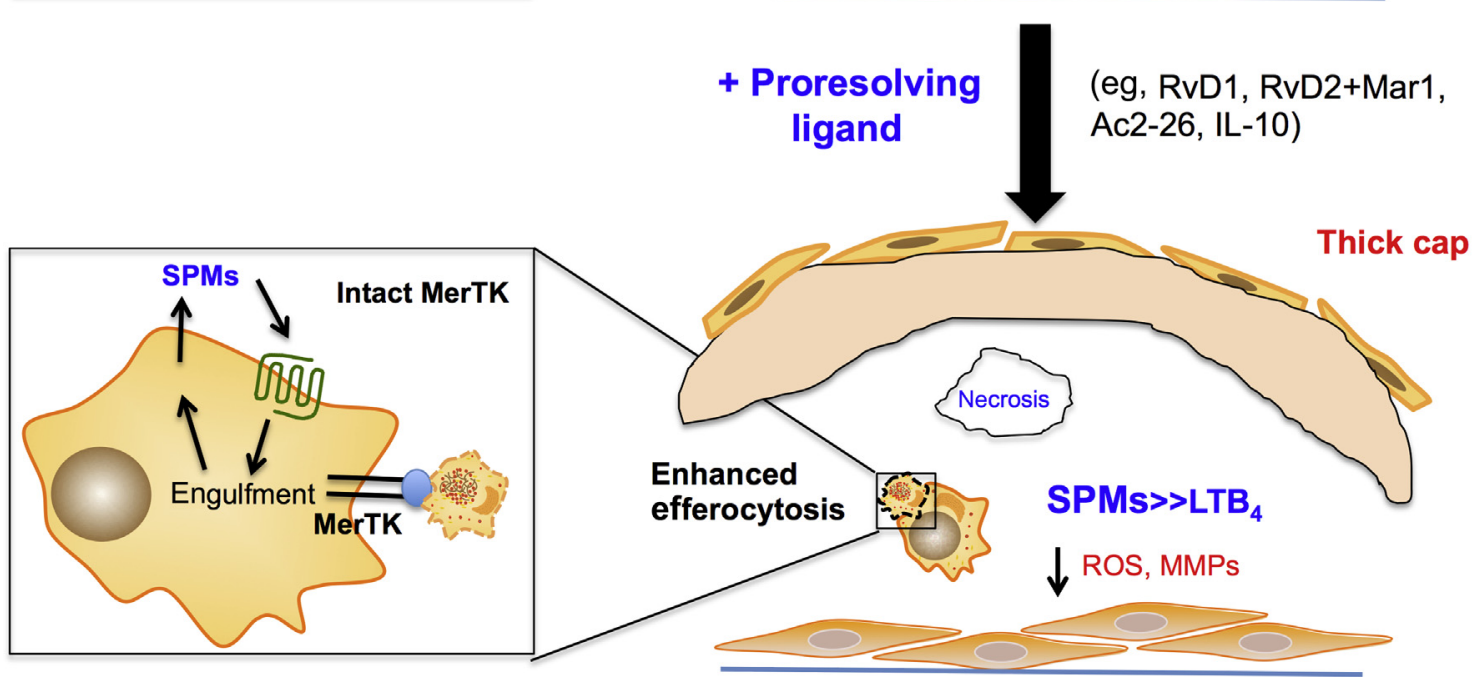

Figure 2 Specialized proresolving mediators (SPMs) reduce lesion necrosis and enhance efferocytosis, fibrous caps, and the SPM/leukotriene (LT) ratio. Top panel: Key features of advanced plaques include large necrotic cores, thin fibrous caps, increased oxidative stress, and a dysregulated activation of matrix metalloproteinases (MMPs) and defective efferocytosis. New results indicate that advanced plaques also have an imbalance in the SPM/LTB ${ }_{4}$ ratio. MerTK is an important receptor for efferocytosis and has recently been linked to the biosynthesis of SPMs. Cleavage of MerTK results in decreased efferocytosis and decreased SPMs. Bottom panel: When SPMs (or other proresolving ligands) are administered to mice with ongoing atherosclerosis, several key features of advanced plaques, like necrosis and oxidative stress, are markedly reduced. SPM administration also increases fibrous cap thickness and efferocytosis and restores the SPM/LTB ratio. RvD1 enhanced lesional efferocytosis in part because of its ability to limit MerTK cleavage. $\mathrm{LTB}_{4}$, leukotriene $\mathrm{B}_{4}$; sol Mer, soluble Mer. 
had accelerated resolution of zymosan-stimulated peritonitis and were protected against ischemia/reperfusion-induced remote organ injury compared with wild-type controls. ${ }^{60}$ Thus, when the impaired resolution cycle is broken, as it is when MerTK is rendered inactive by proteolytic cleavage, the system loses both efferocytosis and the proper balance of proresolving and proinflammatory lipid mediators. It is possible that these new findings could apply to other chronic inflammatory disorders, many of which share defects in both efferocytosis and inflammation resolution. Indeed, in the case of certain diseases, like lupus and Sjögren syndrome, which show positive correlations with soluble Mer, it is possible that MerTK cleavage and thus a disruption of inflammation resolution can be involved. ${ }^{61,62}$ With regard to atherosclerosis, a previous study reported that macrophages near the necrotic cores of human atherosclerotic plaques have lower cell surface MerTK and higher ADAM17 expression compared with peripheral plaque macrophages. ${ }^{63}$ Furthermore, human symptomatic plaques had less surface MerTK compared with asymptomatic plaques. These results were recapitulated in mice, in which advanced, vulnerable plaques had significantly less surface MerTK compared with early plaques. ${ }^{64}$ To test causation, Mertk ${ }^{C R}$ mice has decreased necrotic cores and increased SPM/proinflammatory mediator ratio compared with wild-type controls. ${ }^{64}$ The major class of SPMs that were increased in the Mertk ${ }^{C R}$ plaques was the D-series SPMs. In this regard, administration of RvD1 during plaque progression increased lesional surface MerTK compared with controls, which may be linked to RvD1's ability to enhance lesional efferocytosis (Figure 2). ${ }^{22,64}$ Interestingly, Mertk ${ }^{\mathrm{CR}}$ lesions also had more $\mathrm{T}$ regulatory cells compared with controls. ${ }^{64}$ Key D-series SPMs, such as those identified in human and murine plaques, have been shown to stimulate $\mathrm{T}$ regulatory cells in other contexts ${ }^{65}$ and therefore the increase in $\mathrm{T}$ regulatory cells could be in part because of the increase in D-series SPMs in the Mertk ${ }^{C R}$ plaques. Therefore, in the setting of advanced atherosclerosis, MerTK cleavage promotes many of the features of clinically dangerous plaques, including necrosis, imbalance of proresolving versus proinflammatory lipid mediators, and fibrous cap thinning.

Although the examples above illustrate the concept that defective efferocytosis in atherosclerotic lesions could be caused by abnormalities with the phagocytes themselves, a recent study has shown that apoptotic plaque cells in human and mouse lesions inappropriately retain a don't-eat-me signal called CD47, which is normally present on live cells to block cell engulfment. ${ }^{66}$ Defects on both ends of the efferocytosis pathway in advanced plaques would generate a major impediment to apoptotic cell clearance in lesions. Finally, other studies have provided evidence that necroptosis also contributes to the formation of plaque necrosis, ${ }^{67,68}$ but whether defective clearance of necroptotic cells is important in this process remains to be investigated.

In addition to SPMs, two other protein-derived mediators of resolution, annexin A1 and IL-10, have been shown to be protective in atherosclerosis. The first proof-of-concept study was performed with Ac2-26, which is a bioactive peptide from annexin A1. Ac2-26 was encapsulated into polymeric nanoparticles (NPs) that had a lesion-targeting (collagen-IV) motif. ${ }^{56}$ Administration of collagen-IV Ac2$26 \mathrm{NPs}$ to Western diet-fed $\mathrm{Ldll}^{-1-}$ mice with established atherosclerosis decreased lesional oxidative stress, matrix metalloproteinases, and plaque necrosis in a manner that was dependent on the myeloid cell Ac2-26 receptor, ALX/ FPR2. ${ }^{5,56}$ Collagen-IV Ac2-26 NPs also increased the thickness of the protective fibrous cap, collagen synthesis, and intraplaque IL-10 expression. ${ }^{56}$ Administration of lesion-targeted NPs containing IL-10 also led to an increase in fibrous caps and efferocytosis and a decrease in lesional oxidative stress, necrosis, and matrix metalloproteinases compared with various control treatments. ${ }^{69}$ Systemic IL-10 has anti-inflammatory actions, but this report suggests that targeted, local delivery of IL-10 can have tissue reparative and proresolving actions. ${ }^{69}$ In support of the above Ac2-26 findings, Kusters et $\mathrm{al}^{70}$ subsequently found that treatment with human recombinant annexin A1 decreased lesional necrosis in midadvanced lesions of $\mathrm{Ldlr}^{-1-}$ mice fed a Western diet. Moreover, in early atherogenesis, Drechsler et $\mathrm{al}^{71}$ found that in vivo delivery of Ac2-26 to Western diet-fed Apoe ${ }^{-1-}$ mice quelled atherogenesis in a receptordependent manner. In particular, Ac2-26 decreased lesion area and macrophage number, which is consistent with the known anti-inflammatory and proresolving functions of Ac2-26. To further gain insight into endogenous mechanisms associated with annexin A1-ALX/FPR2 signaling in atherogenesis, Drechsler et $\mathrm{al}^{71}$ studied Apoe ${ }^{-l-} \mathrm{Fpr}^{-1-}$ and Apoe $^{-l-}$ Anxal $^{-l-}$ mice and found that they had increased atherosclerotic lesion area and heightened myeloid cell adhesion and recruitment. Mechanistically, their results indicate an endogenous protective role for annexin A1 and ALX/FPR2 via inhibition of integrin activation evoked by key chemokines. $^{6}$

The SPM resolvin E1 (RvE1) has also been shown to be protective in a rabbit model of atherogenesis. Hasturk et $\mathrm{al}^{21}$ reported that topical administration of RvE1 to the periodontium at the initiation of high cholesterol diet decreased atherogenesis. In this regard, it is intriguing to consider the possibility that SPM-eluting stents or biodegradable wraps could be used to prevent further plaque progression at the time of percutaneous coronary intervention. ${ }^{72}$ Similarly, Salic et $\mathrm{al}^{24}$ found that oral treatment with RvE1 in a mouse model of atherosclerosis decreased lesion area and lesional inflammation without affecting cholesterol levels or systemic inflammatory markers like serum amyloid A. More important, when RvE1 was administered in combination with atorvastatin, plaque size was reduced almost twice as much as with RvE1 alone. ${ }^{24}$ These results suggest that a cotreatment strategy to both lower cholesterol and enhance resolution may be particularly beneficial in preventing plaque progression. In addition to statins, ADP receptor antagonists are another major class of CVD drugs because of their ability to quell platelet aggregation. ${ }^{73}$ Interestingly, 
RvE1 limits ADP-stimulated platelet aggregation, ${ }^{74,75}$ and therefore RvE1 may be an intriguing therapeutic target for CVD because of its multipronged ability to temper inflammation, enhance efferocytosis, and quell ADP-induced platelet aggregation. ${ }^{76}$

\section{SPMs Promote Collagen Synthesis for Wound Healing and Can Help Stabilize Atherosclerotic Plaques}

One of the most striking observations of the plaques in athero-prone mice treated with SPMs or collagen-IV Ac2-26 NPs was a marked increase in fibrous cap thickness and collagen synthesis in plaques. ${ }^{22,23,56}$ Mertk $^{C R}$ mice also had increased fibrous caps, which suggest a role for endogenous SPMs in this process. Although the mechanisms underlying the formation of the protective cap still remain at large, it is possible that efferocytosis can participate in the process. Efferocytosis is known to cause the synthesis and release of transforming growth factor- $\beta$ and SPMs, both of which can trigger collagen synthesis and tissue repair. ${ }^{55,77-79}$ In this regard, RvE1 increased collagen in the context of periodontal ligament repair, ${ }^{80}$ and 17R-RvD1 was shown to increase matrix synthesis in a model of arthritis. ${ }^{81}$ On the other hand, RvD1 was found to decrease cardiac collagen in the setting of myocardial infarction, ${ }^{18}$ and there are several reports that suggest SPMs exert antifibrotic actions. ${ }^{82,83}$ Thus, the role of SPMs in fibrosis appears to be context specific, and factors that control its actions in collagen synthesis in advanced atherosclerosis represent an important area for future investigation.

\section{Emerging Areas of Investigations for the Inflammation-Resolution and Atherosclerosis Fields}

miRNAs are emerging as important regulators of inflammation in atherosclerosis. ${ }^{84-87}$ Interestingly, miR-33 inhibition mirrored many of the same actions of SPMs in plaques, such as an increase in $\mathrm{T}$ regulatory cells, a modest increase in lesional collagen, and a significant decrease in necrosis. ${ }^{84}$ Whether SPMs play a role in regulating miR-33 is unknown.

Oxidative stress is emerging as a process that not only exacerbates atherosclerosis, but also directly impinges on the inflammation-resolution program. ${ }^{22}$ More important, SPMs have been shown to increase heme-oxygenase 1, an endogenous antioxidant protein, in other contexts. ${ }^{88}$ Hemeoxygenase 1 in certain contexts can lead to local production of carbon monoxide, which has recently been linked to a protective phenotype. ${ }^{89}$ Although SPMs have been shown to decrease intraplaque oxidative stress, ${ }^{22}$ it is not known whether the SPM-induced increase in heme-oxygenase 1 contributes to this effect.

Other risk factors for atherosclerosis, such as stress and age, have also been causally linked to atherosclerosis and specifically to features that drive vulnerable plaque formation. ${ }^{90-92}$ Chronic stress, as an example, was shown to induce an inflammatory phenotype. ${ }^{90}$ Therefore, it would be interesting to see whether SPMs could temper the stressinduced inflammatory phenotype and thus decrease stressinduced plaque formation.

Other known factors that exacerbate atherosclerosis include obesity/type 2 diabetes, smoking, arthritis, renal fibrosis, and sex. Table 1 summarizes how SPMs have been reported to be protective in all of these settings. The common thread of these studies is that SPMs temper dysregulated inflammation and promote tissue repair. A deeper mechanistic understanding of how SPMs affect these risk factors will be invaluable for the field.

\section{Proresolution Pathways Stimulate Host Responses and Are Not Immunosuppressive}

Inflammation resolution tempers proinflammatory processes and activates tissue repair/regenerative programs. ${ }^{1}$ Antiinflammation, on the other hand, only refers to the process of limiting proinflammatory processes. The conceptual difference between anti-inflammation and proresolution is highlighted by certain anti-inflammatory therapies, such

Table 1 SPMs Play Protective Roles in Several Factors that Exacerbate Atherosclerosis

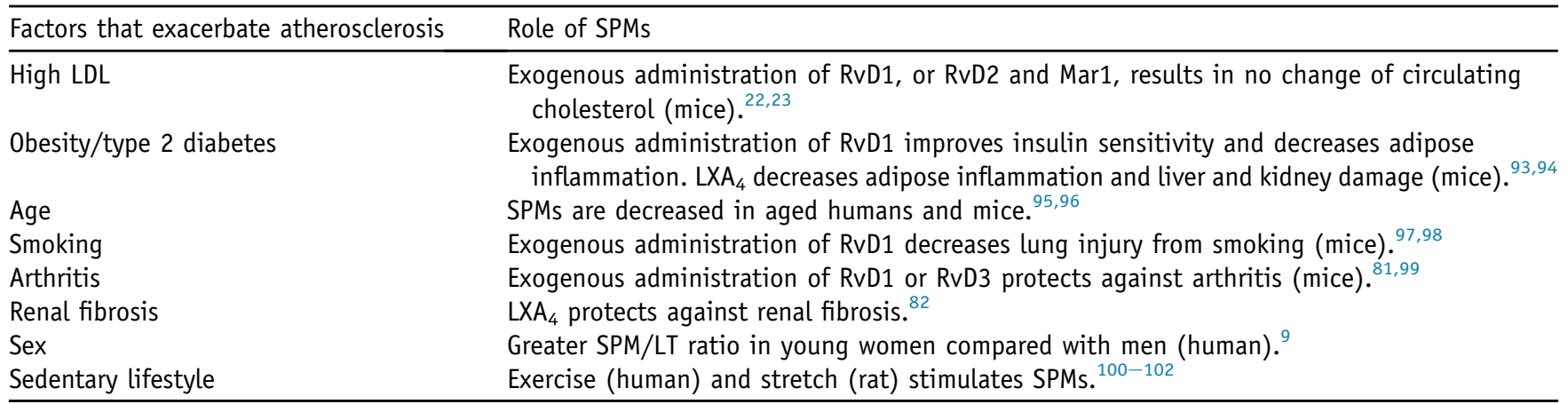

LDL, low-density lipoprotein; LT, leukotriene; $\mathrm{LXA}_{4}$, lipoxin $\mathrm{A}_{4} ;$ Mar1, maresin 1; RvD1, resolvin D1; RvD3, resolvin D3; SPM, specialized proresolving mediator. 
as selective cyclooxygenase-2 and LOX inhibitors. Cyclooxygenase-2 inhibitors disrupt the critical thromboxane $\mathrm{A}_{2} /$ prostacyclin balance and block the production of $\mathrm{PGE}_{2}$ and $\mathrm{PGD}_{2}$ and thus the timely switch to resolution. ${ }^{103,104}$ LOX inhibition in mice significantly exacerbated inflammation, indicated by the increased number of polymorphonuclear leukocytes in exudates at 24 hours and reduced zymosan clearance to lymph nodes. Together, these results indicate a resolution deficit characterized by impaired phagocyte removal. ${ }^{79}$ In contrast, when SPMs were administered together with the LOX inhibitor, the inflammation resolution response was rescued, as evidenced by a marked reduction and removal of exudate polymorphonuclear leukocytes. This overall concept may also help explain the poor clinical outcome observed with anti-tumor necrosis factor- $\alpha$ therapy in systemic inflammatory response syndrome patients (ie, the use of an anti-inflammatory drug may derail a proper and temporal proresolving response). ${ }^{105}$ In summary, it now seems apparent that attempting to block inflammation via inhibition of enzymes or mediators reduces the ability to resolve inflammation. Hence, it is important to develop drugs that do not inhibit the resolution process or, more directly, bolster this response. For example, there are some drugs that are considered inflammation resolution friendly. Low-dose aspirin is widely used for both the primary and secondary prevention of unstable angina, myocardial infarction, and stroke. The beneficial actions of low-dose aspirin in the cardiovascular system are attributed to its ability to decrease the formation of prothrombotic thromboxane $A_{2}$ without suppressing the basal biosynthesis of cardioprotective prostacyclin. ${ }^{106}$ Aspirin has anti-inflammatory actions in humans, such as blocking leukocyte trafficking to inflamed tissues, which is likely independent of aspirin's ability to inhibit prostanoid biosynthesis. ${ }^{103,107}$ In this regard, aspirin has been shown to jump-start inflammation resolution by generating epimeric aspirin-triggered SPMs. As another example of a potentially resolution-friendly drug, statins were reported to augment the production of SPMs in certain contexts, ${ }^{102,108}$ although the benefit of statins in the chronic prevention of heart disease can be explained mostly by their ability to lower plasma levels of low-density lipoprotein.

\section{What the Future Holds for Immunomodulatory CVD Treatment}

Anti-inflammatory drugs, such as synthetic corticosteroids, cyclooxygenase inhibitors, and anti-tumor necrosis factor$\alpha$, are highly efficacious in certain settings, such as in acute inflammation or in symptomatic flares of autoimmune diseases. ${ }^{109}$ In these settings, the adverse effect of these drugs is either minimal because of short-term use or accepted because of the high benefit/risk ratio in symptomatic diseases. ${ }^{109}$ In the context of atherosclerosis, we do not yet have a specific therapeutic approach to the persistently activated inflammatory response, notwithstanding the effects of statin-induced cholesterol lowering on suppressing proinflammatory subendothelial lipoprotein retention. Atherosclerosis is a long-term progressive disease, and so anti-inflammatory drugs that dampen host defense mechanisms or that happen to also disrupt vascular homeostasis (eg, selective cyclooxygenase inhibitors) are not ideal. ${ }^{110}$ For example, recent work indicates that targeting plaques with the anti-inflammatory drug, prednisolone, actually exacerbates atherosclerosis. ${ }^{111,112}$ The burst of new preclinical literature supporting the atheroprotective effect of proresolving mediators suggests that stimulating rather than blocking natural host responses may be the best way to treat CVD.

Precision medicine and functional genomics will likely play important roles in the future of CVD resolution therapeutics. Currently, genetic and genomic patterns controlling resolution are not known and, if uncovered, might provide strategies to tailor current drugs for better use in humans. Patterns associated with post-translational modifications of proteins, or lipid mediators, will also be critical end points for a precision medicine-based treatment approach. Ultimately, the goals would be to identify drugs that impinge on endogenous resolution and to develop new personalized therapeutics that specifically enhance this protective process. Furthermore, understanding the way humans swiftly resolve acute inflammation may also provide clues that can help identify diseases before they develop. In humans, the innate inflammatory response can be assessed by monitoring the systemic inflammatory reaction after endotoxin ${ }^{113,114}$ or the local inflammatory reaction after a cantharidin-induced skin blister, a model of sterile inflammation. ${ }^{115,116}$ Recent findings in humans indicate that SPMs are present in the plasma $^{45,117-119}$ and can possibly serve as temporal biomarkers of inflammation resolution after endotoxin challenge. In addition, lipid mediator signatures may reveal clues for patient outcomes. In this regard, plasma from sepsis patients revealed distinct lipid mediator and SPM patterns associated with surviving versus nonsurviving patients. ${ }^{118}$ Therefore, lipid mediators in the plasma can be identified and quantified to do the following: i) assess an individual's inflammation-resolution response, ${ }^{45,119}$ ii) monitor disease outcomes, ${ }^{118}$ and iii) test the effect of particular drugs on these pathways. ${ }^{120}$

The blister model provides a controlled induction and termination of local inflammation and may be useful as a starting point for genomic and lipid mediator screening and testing of current and novel therapeutics. In this context, Morris et $\mathrm{al}^{121}$ uncovered that humans fall into two categories, those who resolved their acute inflammatory responses in an immediate manner and those who showed a more delayed or prolonged healing process. The magnitude and duration of their acute inflammatory response was controlled by endogenous epimeric lipoxins and ALX/FPR2 expression. More recent results indicate that there are clear sex-specific differences with regard to inflammation- 
resolution responses in humans. ${ }^{9}$ Along these lines, young females exhibited a more controlled inflammatory response compared with males, which was associated with an increase in the SPM/LT ratio. ${ }^{9}$ The class of SPMs that were particularly increased in females were those of the D-series, which include RvD1 and RvD2. More important, these same class of SPMs were decreased in human ${ }^{22}$ and murine plaques. $^{22,23}$ Incorporating a functional genomic approach or identifying a specific signature associated with a defective inflammation-resolution response with human models of swift versus delayed resolution may yield important findings for tailoring specific drugs for individuals for atherosclerotic cardiovascular disease and the other critical diseases in our aging society that are characterized by chronic inflammation and a defective resolution response.

\section{References}

1. Serhan CN: Pro-resolving lipid mediators are leads for resolution physiology. Nature 2014, 510:92-101

2. Nathan C, Ding A: Nonresolving inflammation. Cell 2010, 140: $871-882$

3. Serhan CN, Clish CB, Brannon J, Colgan SP, Chiang N, Gronert K: Novel functional sets of lipid-derived mediators with antiinflammatory actions generated from omega-3 fatty acids via cyclooxygenase 2-nonsteroidal antiinflammatory drugs and transcellular processing. J Exp Med 2000, 192:1197-1204

4. Serhan CN, Hong S, Gronert K, Colgan SP, Devchand PR, Mirick G, Moussignac RL: Resolvins: a family of bioactive products of omega3 fatty acid transformation circuits initiated by aspirin treatment that counter proinflammation signals. J Exp Med 2002, 196:1025-1037

5. Perretti M, Chiang N, La M, Fierro IM, Marullo S, Getting SJ, Solito E, Serhan CN: Endogenous lipid- and peptide-derived antiinflammatory pathways generated with glucocorticoid and aspirin treatment activate the lipoxin A4 receptor. Nat Med 2002, 8: $1296-1302$

6. Wallace JL, Ianaro A, Flannigan KL, Cirino G: Gaseous mediators in resolution of inflammation. Semin Immunol 2015, 27:227-233

7. Shinohara M, Serhan CN: Novel endogenous proresolving molecules: essential fatty acid-derived and gaseous mediators in the resolution of inflammation. J Atheroscler Thromb 2016, 23:655-664

8. Cronstein BN, Montesinos MC, Weissmann G: Salicylates and sulfasalazine, but not glucocorticoids, inhibit leukocyte accumulation by an adenosine-dependent mechanism that is independent of inhibition of prostaglandin synthesis and p105 of NFkappaB. Proc Natl Acad Sci U S A 1999, 96:6377-6381

9. Rathod KS, Kapil V, Velmurugan S, Khambata RS, Siddique U, Khan S, Van Eijl S, Gee LC, Bansal J, Pitrola K, Shaw C, D'Acquisto F, Colas RA, Marelli-Berg F, Dalli J, Ahluwalia A: Accelerated resolution of inflammation underlies sex differences in inflammatory responses in humans. J Clin Invest 2017, 127:169-182

10. Krishnamoorthy S, Recchiuti A, Chiang N, Yacoubian S, Lee CH, Yang R, Petasis NA, Serhan CN: Resolvin D1 binds human phagocytes with evidence for proresolving receptors. Proc Natl Acad Sci U S A 2010, 107:1660-1665

11. Dufton N, Hannon R, Brancaleone V, Dalli J, Patel HB, Gray M, D'Acquisto F, Buckingham JC, Perretti M, Flower RJ: Anti-inflammatory role of the murine formyl-peptide receptor 2: ligand-specific effects on leukocyte responses and experimental inflammation. J Immunol 2010, 184:2611-2619

12. Gobbetti T, Coldewey SM, Chen J, McArthur S, le Faouder P, Cenac N, Flower RJ, Thiemermann C, Perretti M: Nonredundant protective properties of FPR2/ALX in polymicrobial murine sepsis. Proc Natl Acad Sci U S A 2014, 111:18685-18690

13. Chiang N, Dalli J, Colas RA, Serhan CN: Identification of resolvin D2 receptor mediating resolution of infections and organ protection. J Exp Med 2015, 212:1203-1217

14. Fredman G, Li Y, Dalli J, Chiang N, Serhan CN: Self-limited versus delayed resolution of acute inflammation: temporal regulation of proresolving mediators and microRNA. Sci Rep 2012, 2:639

15. Chiang N, Fredman G, Backhed F, Oh SF, Vickery T, Schmidt BA, Serhan $\mathrm{CN}$ : Infection regulates pro-resolving mediators that lower antibiotic requirements. Nature 2012, 484:524-528

16. Miyahara T, Runge S, Chatterjee A, Chen M, Mottola G, Fitzgerald JM, Serhan CN, Conte MS: D-series resolvin attenuates vascular smooth muscle cell activation and neointimal hyperplasia following vascular injury. FASEB J 2013, 27:2220-2232

17. Wu B, Mottola G, Chatterjee A, Lance KD, Chen M, Siguenza IO, Desai TA, Conte MS: Perivascular delivery of resolvin D1 inhibits neointimal hyperplasia in a rat model of arterial injury. J Vasc Surg 2017, 65:207-217e3

18. Kain V, Ingle KA, Colas RA, Dalli J, Prabhu SD, Serhan CN, Joshi M, Halade GV: Resolvin D1 activates the inflammation resolving response at splenic and ventricular site following myocardial infarction leading to improved ventricular function. J Mol Cell Cardiol 2015, 84:24-35

19. Keyes KT, Ye Y, Lin Y, Zhang C, Perez-Polo JR, Gjorstrup P, Birnbaum Y: Resolvin E1 protects the rat heart against reperfusion injury. Am J Physiol Heart Circ Physiol 2010, 299:H153-H164

20. Merched AJ, Ko K, Gotlinger KH, Serhan CN, Chan L: Atherosclerosis: evidence for impairment of resolution of vascular inflammation governed by specific lipid mediators. FASEB J 2008, 22. 3595-3606

21. Hasturk H, Abdallah R, Kantarci A, Nguyen D, Giordano N, Hamilton J, Van Dyke TE: Resolvin E1 (RvE1) attenuates atherosclerotic plaque formation in diet and inflammation-induced atherogenesis. Arterioscler Thromb Vasc Biol 2015, 35:1123-1133

22. Fredman G, Hellmann J, Proto JD, Kuriakose G, Colas RA, Dorweiler B, Connolly ES, Solomon R, Jones DM, Heyer EJ, Spite M, Tabas I: An imbalance between specialized pro-resolving lipid mediators and pro-inflammatory leukotrienes promotes instability of atherosclerotic plaques. Nat Commun 2016, 7:12859

23. Viola JR, Lemnitzer P, Jansen Y, Csaba G, Winter C, Neideck C, Silvestre-Roig C, Dittmar G, Doring Y, Drechsler M, Weber C, Zimmer R, Cenac N, Soehnlein O: Resolving lipid mediators Maresin 1 and Resolvin D2 prevent atheroprogression in mice. Circ Res 2016, 119:1030-1038

24. Salic K, Morrison MC, Verschuren L, Wielinga PY, Wu L, Kleemann R, Gjorstrup P, Kooistra T: Resolvin E1 attenuates atherosclerosis in absence of cholesterol-lowering effects and on top of atorvastatin. Atherosclerosis 2016, 250:158-165

25. Karp CL, Flick LM, Park KW, Softic S, Greer TM, Keledjian R, Yang R, Uddin J, Guggino WB, Atabani SF, Belkaid Y, Xu Y, Whitsett JA, Accurso FJ, Wills-Karp M, Petasis NA: Defective lipoxin-mediated anti-inflammatory activity in the cystic fibrosis airway. Nat Immunol 2004, 5:388-392

26. Levy BD, Bonnans C, Silverman ES, Palmer LJ, Marigowda G, Israel E; Severe Asthma Research Program National Heart, Lung, and Blood Institute: Diminished lipoxin biosynthesis in severe asthma. Am J Respir Crit Care Med 2005, 172:824-830

27. Fredman G, Oh SF, Ayilavarapu S, Hasturk H, Serhan CN, Van Dyke TE: Impaired phagocytosis in localized aggressive periodontitis: rescue by resolvin e1. PLoS One 2011, 6:e24422

28. Bunting S, Moncada S, Vane JR: The prostacyclin-thromboxane A2 balance: pathophysiological and therapeutic implications. Br Med Bull 1983, 39:271-276

29. Coker SJ, Parratt JR, Ledingham IM, Zeitlin IJ: Thromboxane and prostacyclin release from ischaemic myocardium in relation to arrhythmias. Nature 1981, 291:323-324 
30. Brezinski DA, Nesto RW, Serhan CN: Angioplasty triggers intracoronary leukotrienes and lipoxin A4: impact of aspirin therapy. Circulation 1992, 86:56-63

31. Qiu H, Gabrielsen A, Agardh HE, Wan M, Wetterholm A, Wong CH, Hedin U, Swedenborg J, Hansson GK, Samuelsson B, PaulssonBerne G, Haeggstrom JZ: Expression of 5-lipoxygenase and leukotriene A4 hydrolase in human atherosclerotic lesions correlates with symptoms of plaque instability. Proc Natl Acad Sci U S A 2006, 103: $8161-8166$

32. Aiello RJ, Bourassa PA, Lindsey S, Weng W, Freeman A, Showell HJ: Leukotriene B4 receptor antagonism reduces monocytic foam cells in mice. Arterioscler Thromb Vasc Biol 2002, 22:443-449

33. Back M, Bu DX, Branstrom R, Sheikine Y, Yan ZQ, Hansson GK: Leukotriene B4 signaling through NF-kappaB-dependent BLT1 receptors on vascular smooth muscle cells in atherosclerosis and intimal hyperplasia. Proc Natl Acad Sci U S A 2005, 102:17501-17506

34. Zhao L, Moos MP, Grabner R, Pedrono F, Fan J, Kaiser B, John N, Schmidt S, Spanbroek R, Lotzer K, Huang L, Cui J, Rader DJ, Evans JF, Habenicht AJ, Funk CD: The 5-lipoxygenase pathway promotes pathogenesis of hyperlipidemia-dependent aortic aneurysm. Nat Med 2004, 10:966-973

35. Uzonyi B, Lotzer K, Jahn S, Kramer C, Hildner M, Bretschneider E Radke D, Beer M, Vollandt R, Evans JF, Funk CD, Habenicht AJ: Cysteinyl leukotriene 2 receptor and protease-activated receptor 1 activate strongly correlated early genes in human endothelial cells. Proc Natl Acad Sci U S A 2006, 103:6326-6331

36. Helgadottir A, Manolescu A, Helgason A, Thorleifsson G, Thorsteinsdottir U, Gudbjartsson DF, Gretarsdottir S, Magnusson KP, Gudmundsson G, Hicks A, Jonsson T, Grant SF, Sainz J, O’Brien SJ, Sveinbjornsdottir S, Valdimarsson EM, Matthiasson SE, Levey AI, Abramson JL, Reilly MP, Vaccarino V, Wolfe ML, Gudnason V, Quyyumi AA, Topol EJ, Rader DJ, Thorgeirsson G, Gulcher JR, Hakonarson H, Kong A, Stefansson K: A variant of the gene encoding leukotriene A4 hydrolase confers ethnicity-specific risk of myocardial infarction. Nat Genet 2006, 38:68-74

37. Helgadottir A, Manolescu A, Thorleifsson G, Gretarsdottir S, Jonsdottir H, Thorsteinsdottir U, Samani NJ, Gudmundsson G, Grant SF, Thorgeirsson G, Sveinbjornsdottir S, Valdimarsson EM, Matthiasson SE, Johannsson H, Gudmundsdottir O, Gurney ME, Sainz J, Thorhallsdottir M, Andresdottir M, Frigge ML, Topol EJ, Kong A, Gudnason V, Hakonarson H, Gulcher JR, Stefansson K: The gene encoding 5-lipoxygenase activating protein confers risk of myocardial infarction and stroke. Nat Genet 2004, 36:233-239

38. Kajimoto K, Shioji K, Ishida C, Iwanaga Y, Kokubo Y, Tomoike H, Miyazaki S, Nonogi H, Goto Y, Iwai N: Validation of the association between the gene encoding 5-lipoxygenase-activating protein and myocardial infarction in a Japanese population. Circ J 2005, 69: $1029-1034$

39. Wang G, Wang Y, Sun H, Cao W, Zhang J, Xiao H, Zhang J: Variants of the arachidonate 5-lipoxygenase-activating protein (ALOX5AP) gene and risk of ischemic stroke in Han Chinese of eastern China. J Biomed Res 2011, 25:319-327

40. Hakonarson H, Thorvaldsson S, Helgadottir A, Gudbjartsson D, Zink F Andresdottir M, Manolescu A, Arnar DO, Andersen K, Sigurdsson A, Thorgeirsson G, Jonsson A, Agnarsson U, Bjornsdottir H, Gottskalksson G, Einarsson A, Gudmundsdottir H, Adalsteinsdottir AE Gudmundsson K, Kristjansson K, Hardarson T, Kristinsson A, Topol EJ, Gulcher J, Kong A, Gurney M, Thorgeirsson G, Stefansson K: Effects of a 5-lipoxygenase-activating protein inhibitor on biomarkers associated with risk of myocardial infarction: a randomized trial. JAMA 2005, 293: 2245-2256

41. Dwyer JH, Allayee H, Dwyer KM, Fan J, Wu H, Mar R, Lusis AJ, Mehrabian M: Arachidonate 5-lipoxygenase promoter genotype, dietary arachidonic acid, and atherosclerosis. N Engl J Med 2004, 350: 29-37

42. ORIGIN Trial Investigators, Bosch J, Gerstein HC, Dagenais GR, Diaz R, Dyal L, Jung H, Maggiono AP, Probstfield J,
Ramachandran A, Riddle MC, Ryden LE, Yusuf S: n-3 fatty acids and cardiovascular outcomes in patients with dysglycemia. N Engl J Med 2012, 367:309-318

43. Tsai MY, Cao J, Steffen BT, Weir NL, Rich SS, Liang S, Guan W: 5-Lipoxygenase gene variants are not associated with atherosclerosis or incident coronary heart disease in the multi-ethnic study of atherosclerosis cohort. J Am Heart Assoc 2016, 5:e002814

44. Ho KJ, Spite M, Owens CD, Lancero H, Kroemer AH, Pande R, Creager MA, Serhan CN, Conte MS: Aspirin-triggered lipoxin and resolvin E1 modulate vascular smooth muscle phenotype and correlate with peripheral atherosclerosis. Am J Pathol 2010, 177: $2116-2123$

45. Elajami TK, Colas RA, Dalli J, Chiang N, Serhan CN, Welty FK: Specialized proresolving lipid mediators in patients with coronary artery disease and their potential for clot remodeling. FASEB J 2016, 30:2792-2801

46. Fredman G, Ozcan L, Spolitu S, Hellmann J, Spite M, Backs J, Tabas I: Resolvin D1 limits 5-lipoxygenase nuclear localization and leukotriene B4 synthesis by inhibiting a calcium-activated kinase pathway. Proc Natl Acad Sci U S A 2014, 111:14530-14535

47. Woods JW, Evans JF, Ethier D, Scott S, Vickers PJ, Hearn L, Heibein JA, Charleson S, Singer II: 5-lipoxygenase and 5-lipoxygenase-activating protein are localized in the nuclear envelope of activated human leukocytes. J Exp Med 1993, 178:1935-1946

48. Serhan CN, Haeggstrom JZ, Leslie CC: Lipid mediator networks in cell signaling: update and impact of cytokines. FASEB J 1996, 10: $1147-1158$

49. Lehmann C, Homann J, Ball AK, Blocher R, Kleinschmidt TK, Basavarajappa D, Angioni C, Ferreiros N, Hafner AK, Radmark O, Proschak E, Haeggstrom JZ, Geisslinger G, Parnham MJ, Steinhilber D, Kahnt AS: Lipoxin and resolvin biosynthesis is dependent on 5lipoxygenase activating protein. FASEB J 2015, 29:5029-5043

50. Elias I, Ferre T, Vila L, Munoz S, Casellas A, Garcia M, Molas M, Agudo J, Roca C, Ruberte J, Bosch F, Franckhauser S: ALOX5AP overexpression in adipose tissue leads to LXA4 production and protection against diet-induced obesity and insulin resistance. Diabetes 2016, 65:2139-2150

51. Norris PC, Gosselin D, Reichart D, Glass CK, Dennis EA: Phospholipase A2 regulates eicosanoid class switching during inflammasome activation. Proc Natl Acad Sci U S A 2014, 111:12746-12751

52. Sansbury BE, Spite M: Resolution of acute inflammation and the role of resolvins in immunity, thrombosis, and vascular biology. Circ Res 2016, 119:113-130

53. Libby P, Tabas I, Fredman G, Fisher EA: Inflammation and its resolution as determinants of acute coronary syndromes. Circ Res 2014, 114:1867-1879

54. Godson C, Mitchell S, Harvey K, Petasis NA, Hogg N, Brady HR: Cutting edge: lipoxins rapidly stimulate nonphlogistic phagocytosis of apoptotic neutrophils by monocyte-derived macrophages. J Immunol 2000, 164:1663-1667

55. Tabas I: Macrophage death and defective inflammation resolution in atherosclerosis. Nat Rev Immunol 2010, 10:36-46

56. Fredman G, Kamaly N, Spolitu S, Milton J, Ghorpade D, Chiasson R, Kuriakose G, Perretti M, Farokhzad O, Tabas I: Targeted nanoparticles containing the proresolving peptide Ac2-26 protect against advanced atherosclerosis in hypercholesterolemic mice. Sci Transl Med 2015, 7:275ra20

57. Ait-Oufella H, Pouresmail V, Simon T, Blanc-Brude O, Kinugawa K, Merval R, Offenstadt G, Leseche G, Cohen PL, Tedgui A, Mallat Z: Defective mer receptor tyrosine kinase signaling in bone marrow cells promotes apoptotic cell accumulation and accelerates atherosclerosis. Arterioscler Thromb Vasc Biol 2008, 28:1429-1431

58. Thorp E, Cui D, Schrijvers DM, Kuriakose G, Tabas I: Mertk receptor mutation reduces efferocytosis efficiency and promotes apoptotic cell accumulation and plaque necrosis in atherosclerotic lesions of apoe-/- mice. Arterioscler Thromb Vasc Biol 2008, 28: $1421-1428$ 
59. Thorp E, Vaisar T, Subramanian M, Mautner L, Blobel C, Tabas I: Shedding of the Mer tyrosine kinase receptor is mediated by ADAM17 protein through a pathway involving reactive oxygen species, protein kinase Cdelta, and p38 mitogen-activated protein kinase (MAPK). J Biol Chem 2011, 286:33335-33344

60. Cai B, Thorp EB, Doran AC, Subramanian M, Sansbury BE, Lin CS, Spite M, Fredman G, Tabas I: MerTK cleavage limits proresolving mediator biosynthesis and exacerbates tissue inflammation. Proc Natl Acad Sci U S A 2016, 113:6526-6531

61. Zizzo G, Guerrieri J, Dittman LM, Merrill JT, Cohen PL: Circulating levels of soluble MER in lupus reflect M2c activation of monocytes/macrophages, autoantibody specificities and disease activity. Arthritis Res Ther 2013, 15:R212

62. Qin B, Wang J, Ma N, Yang M, Fu H, Liang Y, Huang F, Yang Z, Zhong R: The association of Tyro3/Axl/Mer signaling with inflammatory response, disease activity in patients with primary Sjogren's syndrome. Joint Bone Spine 2015, 82:258-263

63. Garbin U, Baggio E, Stranieri C, Pasini A, Manfro S, Mozzini C, Vallerio P, Lipari G, Merigo F, Guidi G, Cominacini L, Fratta Pasini A: Expansion of necrotic core and shedding of Mertk receptor in human carotid plaques: a role for oxidized polyunsaturated fatty acids? Cardiovasc Res 2013, 97:125-133

64. Cai B, Thorp EB, Doran AC, Sansbury BE, Daemen MJ, Dorweiler B, Spite M, Fredman G, Tabas I: MerTK receptor cleavage promotes plaque necrosis and defective resolution in atherosclerosis. J Clin Invest 2017, 127:564-568

65. Chiurchiu V, Leuti A, Dalli J, Jacobsson A, Battistini L, Maccarrone M, Serhan CN: Proresolving lipid mediators resolvin D1, resolvin D2, and maresin 1 are critical in modulating $\mathrm{T}$ cell responses. Sci Transl Med 2016, 8:353ra111

66. Kojima Y, Volkmer JP, McKenna K, Civelek M, Lusis AJ, Miller CL, Direnzo D, Nanda V, Ye J, Connolly AJ, Schadt EE, Quertermous T, Betancur P, Maegdefessel L, Matic LP, Hedin U, Weissman IL, Leeper NJ: CD47-blocking antibodies restore phagocytosis and prevent atherosclerosis. Nature 2016, 536:86-90

67. Karunakaran D, Geoffrion M, Wei L, Gan W, Richards L, Shangari P, DeKemp EM, Beanlands RA, Perisic L, Maegdefessel L, Hedin U, Sad S, Guo L, Kolodgie FD, Virmani R, Ruddy T, Rayner KJ: Targeting macrophage necroptosis for therapeutic and diagnostic interventions in atherosclerosis. Sci Adv 2016, 2:e1600224

68. Lin J, Li H, Yang M, Ren J, Huang Z, Han F, Huang J, Ma J, Zhang D, Zhang Z, Wu J, Huang D, Qiao M, Jin G, Wu Q, Huang Y, Du J, Han J: A role of RIP3-mediated macrophage necrosis in atherosclerosis development. Cell Rep 2013, 3:200-210

69. Kamaly N, Fredman G, Fojas JJ, Subramanian M, Choi WI, Zepeda K, Vilos C, Yu M, Gadde S, Wu J, Milton J, Carvalho Leitao R, Rosa Fernandes L, Hasan M, Gao H, Nguyen V, Harris J, Tabas I, Farokhzad OC: Targeted interleukin-10 nanotherapeutics developed with a microfluidic chip enhance resolution of inflammation in advanced atherosclerosis. ACS Nano 2016, 10:5280-5292

70. Kusters DH, Chatrou ML, Willems BA, De Saint-Hubert M, Bauwens M, van der Vorst E, Bena S, Biessen EA, Perretti M, Schurgers LJ, Reutelingsperger CP: Pharmacological treatment with Annexin A1 reduces atherosclerotic plaque burden in LDLR-/- mice on western type diet. PLoS One 2015, 10:e130484

71. Drechsler M, de Jong R, Rossaint J, Viola JR, Leoni G, Wang JM, Grommes J, Hinkel R, Kupatt C, Weber C, Doring Y, Zarbock A, Soehnlein O: Annexin A1 counteracts chemokine-induced arterial myeloid cell recruitment. Circ Res 2015, 116:827-835

72. Lance KD, Chatterjee A, Wu B, Mottola G, Nuhn H, Lee PP, Sansbury BE, Spite M, Desai TA, Conte MS: Unidirectional and sustained delivery of the proresolving lipid mediator resolvin D1 from a biodegradable thin film device. J Biomed Mater Res A 2017, 105: $31-41$

73. Damman P, Woudstra P, Kuijt WJ, de Winter RJ, James SK: P2Y12 platelet inhibition in clinical practice. J Thromb Thrombolysis 2012, $33: 143-153$
74. Fredman G, Van Dyke TE, Serhan CN: Resolvin E1 regulates adenosine diphosphate activation of human platelets. Arterioscler Thromb Vasc Biol 2010, 30:2005-2013

75. Dona M, Fredman G, Schwab JM, Chiang N, Arita M, Goodarzi A, Cheng G, von Andrian UH, Serhan CN: Resolvin E1, an EPAderived mediator in whole blood, selectively counterregulates leukocytes and platelets. Blood 2008, 112:848-855

76. Fredman G, Serhan CN: Specialized proresolving mediator targets for RvE1 and RvD1 in peripheral blood and mechanisms of resolution. Biochem J 2011, 437:185-197

77. Dalli J, Serhan CN: Specific lipid mediator signatures of human phagocytes: microparticles stimulate macrophage efferocytosis and pro-resolving mediators. Blood 2012, 120:e60-e72

78. Huynh ML, Fadok VA, Henson PM: Phosphatidylserine-dependent ingestion of apoptotic cells promotes TGF-betal secretion and the resolution of inflammation. J Clin Invest 2002, 109:41-50

79. Schwab JM, Chiang N, Arita M, Serhan CN: Resolvin E1 and protectin D1 activate inflammation-resolution programmes. Nature 2007, 447:869-874

80. Hasturk H, Kantarci A, Goguet-Surmenian E, Blackwood A, Andry C, Serhan CN, Van Dyke TE: Resolvin E1 regulates inflammation at the cellular and tissue level and restores tissue homeostasis in vivo. J Immunol 2007, 179:7021-7029

81. Norling LV, Headland SE, Dalli J, Arnardottir HH, Haworth O, Jones HR, Irimia D, Serhan CN, Perretti M: Proresolving and cartilage-protective actions of resolvin D1 in inflammatory arthritis. JCI Insight 2016, 1:e85922

82. Borgeson E, Docherty NG, Murphy M, Rodgers K, Ryan A, O'Sullivan TP, Guiry PJ, Goldschmeding R, Higgins DF, Godson C: Lipoxin $\mathrm{A}(4)$ and benzo-lipoxin $\mathrm{A}(4)$ attenuate experimental renal fibrosis. FASEB J 2011, 25:2967-2979

83. Yatomi M, Hisada T, Ishizuka T, Koga Y, Ono A, Kamide Y, Seki K, Aoki-Saito H, Tsurumaki H, Sunaga N, Kaira K, Dobashi K, Yamada M, Okajima F: 17(R)-resolvin D1 ameliorates bleomycininduced pulmonary fibrosis in mice. Physiol Rep 2015, 3:e12628

84. Ouimet M, Ediriweera HN, Gundra UM, Sheedy FJ, Ramkhelawon B, Hutchison SB, Rinehold K, van Solingen C, Fullerton MD, Cecchini K, Rayner KJ, Steinberg GR, Zamore PD, Fisher EA, Loke P, Moore KJ: MicroRNA-33-dependent regulation of macrophage metabolism directs immune cell polarization in atherosclerosis. J Clin Invest 2015, 125:4334-4348

85. Sun X, Icli B, Wara AK, Belkin N, He S, Kobzik L, Hunninghake GM, Vera MP, Registry M, Blackwell TS, Baron RM, Feinberg MW: MicroRNA-181b regulates NF-kappaB-mediated vascular inflammation. J Clin Invest 2012, 122:1973-1990

86. Li K, Ching D, Luk FS, Raffai RL: Apolipoprotein E enhances microRNA-146a in monocytes and macrophages to suppress nuclear factor-kappaB-driven inflammation and atherosclerosis. Circ Res 2015, 117:e1-e11

87. Feinberg MW, Moore KJ: MicroRNA regulation of atherosclerosis. Circ Res 2016, 118:703-720

88. Biteman B, Hassan IR, Walker E, Leedom AJ, Dunn M, Seta F, Laniado-Schwartzman M, Gronert K: Interdependence of lipoxin A4 and heme-oxygenase in counter-regulating inflammation during corneal wound healing. FASEB J 2007, 21:2257-2266

89. Shinohara M, Kibi M, Riley IR, Chiang N, Dalli J, Kraft BD, Piantadosi CA, Choi AM, Serhan CN: Cell-cell interactions and bronchoconstrictor eicosanoid reduction with inhaled carbon monoxide and resolvin D1. Am J Physiol Lung Cell Mol Physiol 2014, 307:L746-L757

90. Heidt T, Sager HB, Courties G, Dutta P, Iwamoto Y, Zaltsman A, von Zur Muhlen C, Bode C, Fricchione GL, Denninger J, Lin CP, Vinegoni C, Libby P, Swirski FK, Weissleder R, Nahrendorf M: Chronic variable stress activates hematopoietic stem cells. Nat Med 2014, 20:754-758

91. Du W, Wong C, Song Y, Shen H, Mori D, Rotllan N, Price N, Dobrian AD, Meng H, Kleinstein SH, Fernandez-Hernando C, 
Goldstein DR: Age-associated vascular inflammation promotes monocytosis during atherogenesis. Aging Cell 2016, 15:766-777

92. Collins AR, Lyon CJ, Xia X, Liu JZ, Tangirala RK, Yin F, Boyadjian R, Bikineyeva A, Pratico D, Harrison DG, Hsueh WA: Age-accelerated atherosclerosis correlates with failure to upregulate antioxidant genes. Circ Res 2009, 104:e42-e54

93. Hellmann J, Tang Y, Kosuri M, Bhatnagar A, Spite M: Resolvin D1 decreases adipose tissue macrophage accumulation and improves insulin sensitivity in obese-diabetic mice. FASEB J 2011, 25:2399-2407

94. Borgeson E, Johnson AM, Lee YS, Till A, Syed GH, Ali-Shah ST, Guiry PJ, Dalli J, Colas RA, Serhan CN, Sharma K, Godson C: Lipoxin A4 attenuates obesity-induced adipose inflammation and associated liver and kidney disease. Cell Metab 2015, 22:125-137

95. Gangemi S, Pescara L, D’Urbano E, Basile G, Nicita-Mauro V, Davi G, Romano M: Aging is characterized by a profound reduction in anti-inflammatory lipoxin A4 levels. Exp Gerontol 2005, 40: 612-614

96. Arnardottir HH, Dalli J, Colas RA, Shinohara M, Serhan CN: Aging delays resolution of acute inflammation in mice: reprogramming the host response with novel nano-proresolving medicines. J Immunol 2014, 193:4235-4244

97. Hsiao HM, Sapinoro RE, Thatcher TH, Croasdell A, Levy EP, Fulton RA, Olsen KC, Pollock SJ, Serhan CN, Phipps RP, Sime PJ: A novel anti-inflammatory and pro-resolving role for resolvin D1 in acute cigarette smoke-induced lung inflammation. PLoS One 2013, 8: e58258

98. Kim KH, Park TS, Kim YS, Lee JS, Oh YM, Lee SD, Lee SW: Resolvin D1 prevents smoking-induced emphysema and promotes lung tissue regeneration. Int J Chron Obstruct Pulmon Dis 2016, 11: $1119-1128$

99. Arnardottir HH, Dalli J, Norling LV, Colas RA, Perretti M, Serhan CN: Resolvin D3 is dysregulated in arthritis and reduces arthritic inflammation. J Immunol 2016, 197:2362-2368

100. Gangemi S, Luciotti G, D’Urbano E, Mallamace A, Santoro D, Bellinghieri G, Davi G, Romano M: Physical exercise increases urinary excretion of lipoxin A4 and related compounds. J Appl Physiol 2003, 94:2237-2240

101. Berrueta L, Muskaj I, Olenich S, Butler T, Badger GJ, Colas RA, Spite M, Serhan CN, Langevin HM: Stretching impacts inflammation resolution in connective tissue. J Cell Physiol 2016, 231:1621-1627

102. Dalli J, Chiang N, Serhan CN: Elucidation of novel 13-series resolvins that increase with atorvastatin and clear infections. Nat Med 2015, 21:1071-1075

103. Gilroy DW, Colville-Nash PR, Willis D, Chivers J, Paul-Clark MJ, Willoughby DA: Inducible cyclooxygenase may have antiinflammatory properties. Nat Med 1999, 5:698-701

104. Levy BD, Clish CB, Schmidt B, Gronert K, Serhan CN: Lipid mediator class switching during acute inflammation: signals in resolution. Nat Immunol 2001, 2:612-619

105. Serhan CN, Brain SD, Buckley CD, Gilroy DW, Haslett C, O'Neill LA, Perretti M, Rossi AG, Wallace JL: Resolution of inflammation: state of the art, definitions and terms. FASEB J 2007, $21: 325-332$

106. Vane JR, Botting RM: The mechanism of action of aspirin. Thromb Res 2003, 110:255-258

107. Paul-Clark MJ, Van Cao T, Moradi-Bidhendi N, Cooper D, Gilroy DW: 15-epi-lipoxin A4-mediated induction of nitric oxide explains how aspirin inhibits acute inflammation. J Exp Med 2004, 200:69-78
108. Birnbaum Y, Ye Y, Lin Y, Freeberg SY, Nishi SP, Martinez JD, Huang MH, Uretsky BF, Perez-Polo JR: Augmentation of myocardial production of 15-epi-lipoxin-a4 by pioglitazone and atorvastatin in the rat. Circulation 2006, 114:929-935

109. Tabas I, Glass CK: Anti-inflammatory therapy in chronic disease: challenges and opportunities. Science 2013, 339:166-172

110. Canny G, Levy O, Furuta GT, Narravula-Alipati S, Sisson RB, Serhan CN, Colgan SP: Lipid mediator-induced expression of bactericidal/permeability-increasing protein (BPI) in human mucosal epithelia. Proc Natl Acad Sci U S A 2002, 99:3902-3907

111. van der Valk FM, van Wijk DF, Lobatto ME, Verberne HJ, Storm G, Willems MC, Legemate DA, Nederveen AJ, Calcagno C, Mani V, Ramachandran S, Paridaans MP, Otten MJ, Dallinga-Thie GM, Fayad ZA, Nieuwdorp M, Schulte DM, Metselaar JM, Mulder WJ, Stroes ES: Prednisolone-containing liposomes accumulate in human atherosclerotic macrophages upon intravenous administration. Nanomedicine 2015, 11:1039-1046

112. van der Valk FM, Schulte DM, Meiler S, Tang J, Zheng KH, Van den Bossche J, Seijkens T, Laudes M, de Winther M, Lutgens E, Alaarg A, Metselaar JM, Dallinga-Thie GM, Mulder WJ, Stroes ES, Hamers AA: Liposomal prednisolone promotes macrophage lipotoxicity in experimental atherosclerosis. Nanomedicine 2016, 12: $1463-1470$

113. Michel O, Nagy AM, Schroeven M, Duchateau J, Neve J, Fondu P, Sergysels R: Dose-response relationship to inhaled endotoxin in normal subjects. Am J Respir Crit Care Med 1997, 156:1157-1164

114. Patel PN, Shah RY, Ferguson JF, Reilly MP: Human experimental endotoxemia in modeling the pathophysiology, genomics, and therapeutics of innate immunity in complex cardiometabolic diseases. Arterioscler Thromb Vasc Biol 2015, 35:525-534

115. Day RM, Harbord M, Forbes A, Segal AW: Cantharidin blisters: a technique for investigating leukocyte trafficking and cytokine production at sites of inflammation in humans. J Immunol Methods 2001, 257:213-220

116. Jenner WJ, Gilroy DW: Assessment of leukocyte trafficking in humans using the cantharidin blister model. JRSM Cardiovasc Dis 2012, 1:e87031. doi:10.1172/jci.insight. 87031

117. Colas RA, Shinohara M, Dalli J, Chiang N, Serhan CN: Identification and signature profiles for pro-resolving and inflammatory lipid mediators in human tissue. Am J Physiol Cell Physiol 2014, 307: C39-C54

118. Dalli J, Colas RA, Quintana C, Barragan-Bradford D, Hurwitz S, Levy BD, Choi AM, Serhan CN, Baron RM: Human sepsis eicosanoid and proresolving lipid mediator temporal profiles: correlations with survival and clinical outcomes. Crit Care Med 2017, $45: 58-68$

119. Markworth JF, Kaur G, Miller EG, Larsen AE, Sinclair AJ, Maddipati KR, Cameron-Smith D: Divergent shifts in lipid mediator profile following supplementation with $\mathrm{n}-3$ docosapentaenoic acid and eicosapentaenoic acid. FASEB J 2016, 30:3714-3725

120. Mazaleuskaya LL, Lawson JA, Li X, Grant G, Mesaros C, Grosser T, Blair IA, Ricciotti E, FitzGerald GA: A broad-spectrum lipidomics screen of antiinflammatory drug combinations in human blood. JCI Insight 2016. pii:e87031. doi:10.1172/jci.insight.87031

121. Morris T, Stables M, Colville-Nash P, Newson J, Bellingan G, de Souza PM, Gilroy DW: Dichotomy in duration and severity of acute inflammatory responses in humans arising from differentially expressed proresolution pathways. Proc Natl Acad Sci U S A 2010, 107:8842-8847 